\title{
Stereodivergent approach in the protected glycal synthesis of L-vancosamine, L-saccharosamine, L-daunosamine and L-ristosamine involving a ring-closing metathesis step
}

\author{
Pierre-Antoine Nocquet ${ }^{1}$, Aurélie Macé ${ }^{1}$, Frédéric Legros ${ }^{2}$, Jacques Lebreton ${ }^{3}$, \\ Gilles Dujardin ${ }^{2}$, Sylvain Collet ${ }^{3}$, Arnaud Martel ${ }^{2}$, Bertrand Carboni ${ }^{1}$ \\ and François Carreaux ${ }^{* 1}$
}

\section{Full Research Paper}

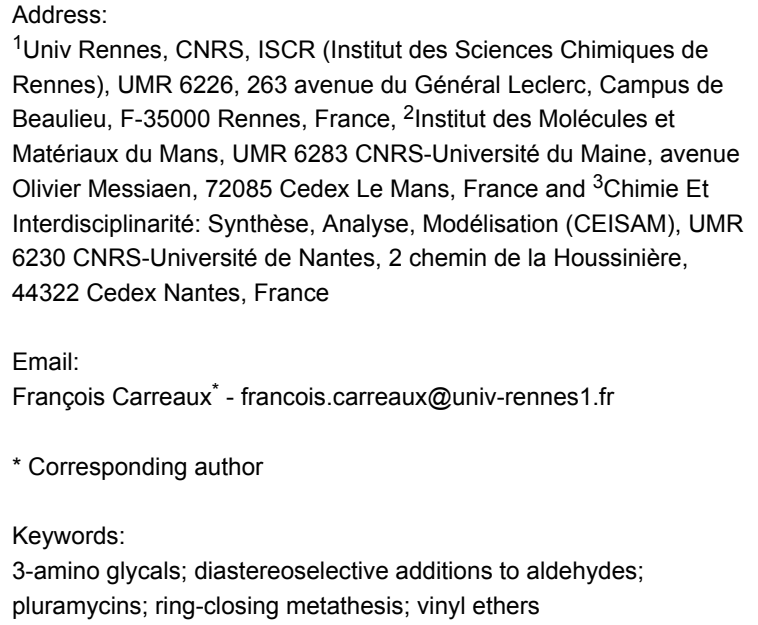

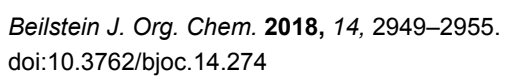

\begin{abstract}
In this paper, a new access to several chiral 3-aminoglycals as potential precursors for glycosylated natural products is reported from a common starting material, $(-)$-methyl-L-lactate. The stereodivergent strategy is based on the implementation of a ringclosing metathesis of vinyl ethers as key step of reaction sequences developed.
\end{abstract}

\section{Introduction}

Several classes of medicinally useful molecules with antibiotic and anticancer activity contain in their structures 3-amino-2deoxy sugars [1]. For instance, $N, N$-dimethyl-L-vancosamine is an essential component of pluramycin antibiotics such as kidamycin and pluramycin A via a $\mathrm{C}$-glycosidic linkage (Figure 1).
For constructing aryl C-glycoside bonds, glycal derivatives are versatile synthetic intermediates (Figure 2). Indeed, they can be converted into glycosyl donors but can also be considered as potential coupling partners or nucleophilic moieties via the formation of transient metalated species [2]. As example concerning their use in pluramycins' syntheses, an approach to the syn- 


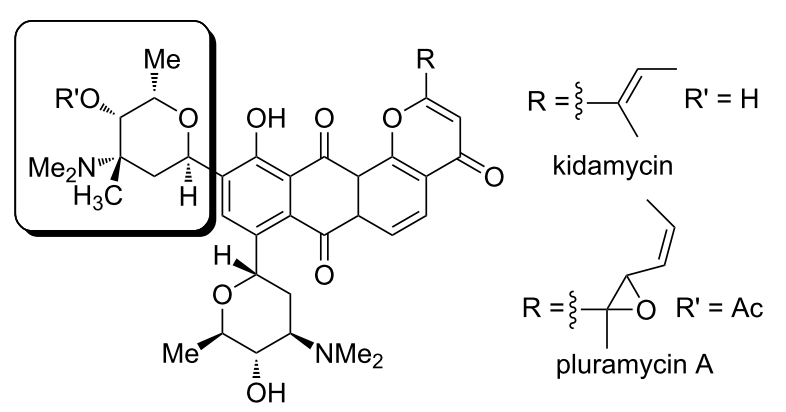

Figure 1: $\mathrm{N}, \mathrm{N}$-Dimethyl-L-vancosamine as substructure of kidamycin and pluramycin.

thesis of pluraflavin A was developed based on a Stille coupling to install the C-linked sugar residue [3]. Moreover, the addition of lithiated glycals to quinone derivatives followed by a rearrangement was also studied for the synthesis of kidamycin according to a "reverse polarity" strategy $[4,5]$.

Considering that the glycal scaffolds are versatile building blocks with multiple applications in the field of natural product synthesis [6], the development of new asymmetric synthetic sequences with stereochemical diversity is still of high interest. Different approaches have been reported for the asymmetric synthesis of protected 3-aminoglycals from non-carbohydrate precursors. Most of them used a common methodology for the construction of the pyranosyl glycal ring which is based on a cycloisomerization reaction of chiral homopropargylic alcohols [7-10]. In some cases, the strategy used for the preparation of the corresponding alkynyl alcohols requires the handling of toxic tin reagents $[8,9]$.

During these last years, ring-closing metathesis (RCM) of vinyl ethers have proved to be an efficient method for the preparation of chiral glycal scaffolds [11-18] as demonstrated in some total syntheses of marine polycyclic ethers [19-21]. However, to the best of our knowledge, this methodology was never evaluated for the synthesis of this kind of nitrogen-containing substrates. Taking into account our interest about the development of new synthetic approaches to pluramycins [22,23], we speculated that the cyclic vinyl ether derivative $\mathbf{I}$, with the prerequisite configuration of all stereogenic centers of the carbamate-protected glycal of L-vancosamine 1, could be obtained from the alcohol derivative II using an O-vinylation-ring-closing metathesis sequence (Figure 3). Afterwards, the introduction of nitrogen in the convenient position (C3) could be performed by a stereopecific nitrene insertion reaction catalyzed by rhodium(II) complexes [24,25].

Herein, we describe our outcomes related to the implementation of this strategy for the synthesis of L-vancosamine derivative $\mathbf{1}$, as well as its diastereoisomer, the carbamate-protected 3 -aminoglycal of L-saccharosamine 2 , employing the $(S)-(-)$-methyl lactate as common starting material. The efficiency and generality of this methodology was also demonstrated by a new synthesis of C-3 unbranched amino glycals, L-daunosamine 3 and L-ristosamine $\mathbf{4}$ derivatives, from the same source of chirality.

\section{Results and Discussion}

Synthesis of vancosamine and saccharosamine glycals. The chiral (-)-lactic methyl ester was identified as the privileged starting material considering that the Evans aldol reaction via boron enolates [26-28] with an appropriately O-protected aldehyde should afford the desired aldol adduct with a syn relative configuration between the two newly created chiral centers $[29,30]$. Moreover, the boron-mediated stereoselective aldol reaction is all the more interesting for our synthetic plan as stereochemical diversity can be generated depending on the absolute configuration of the chiral auxiliary used. The aldehyde 5 was first prepared according to a described procedure in two steps from methyl L-lactate (Scheme 1) [31]. The reaction with $(R)$ - or $(S)$-oxazolidinones 6 led to the formation of 2,3-syn aldol products 7 in good yields with a very high level of diastereoselection ( $>20: 1$ for both).

Figure 2: Glycals as relevant scaffolds for constructing aryl C-glycosidic linkage. 


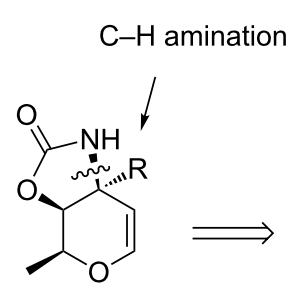

1, $\mathrm{R}=\mathrm{Me}$

L-vancosamine glycal

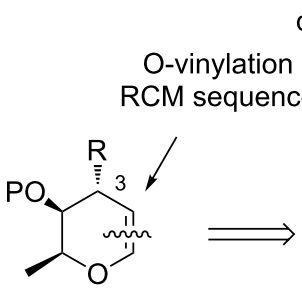

I diastereoselective<smiles>[R]C(C=C)C([R6])C(C)O</smiles>

II methyl (S)-lactate<smiles>CC1OC=C[C@]2(C)NC(=O)OC12</smiles>

2

L-saccharosamine glycal<smiles>CC1OC=CC2NC(=O)OC21</smiles>

3

L-daunosamine glycal<smiles>C[C@H]1OC=C[C@@H]2NC(=O)O[C@@H]21</smiles>

4

Figure 3: Strategy including a ring-closing metathesis of vinyl ethers as key step for the preparation of several carbamate-protected 3-aminoglycals.
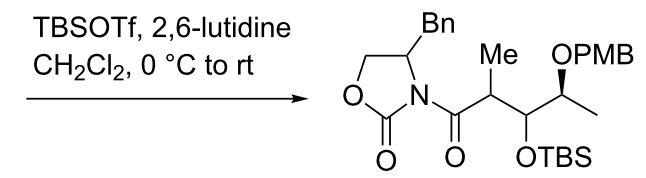

$(2 S, 3 S)-8 \mathbf{a}, 85 \%$ $(2 R, 3 R)-8 b, 79 \%$

DMSO, $(\mathrm{ClCO})_{2}$ $\mathrm{Et}_{3} \mathrm{~N}, \mathrm{CH}_{2} \mathrm{Cl}_{2}$ $-78{ }^{\circ} \mathrm{C}$ to rt

$\mathrm{LiBH}_{4}, \mathrm{H}_{2} \mathrm{O}$<smiles>CCO[Co+][O+]</smiles>

$\mathrm{Ph}_{3} \mathrm{PCH}_{3} \mathrm{Br}, n$-BuLi THF, $-78^{\circ} \mathrm{C}$ to $\mathrm{rt}$<smiles>CCCCCC(C)OC(C)C(C)C=O</smiles>

(2S,3S)-11a, $96 \%$ $(2 R, 3 R)-11 \mathrm{~b}, 73 \%$<smiles>CCCCCC(C)O[Mg]C(C)C(O)C(C)C(=O)N1C(=O)OCC1Cc1ccccc1</smiles>

$(2 S, 3 S)-7 a, 90 \%,(d r>20: 1)$

$(2 R, 3 R)-7 \mathrm{~b}, 96 \%,(\mathrm{dr}>20: 1)$<smiles>CCCCC(C)OC(C)C(O[SbH3])C(C)CO</smiles>

(2R,3S)-9a, 66\% $(2 S, 3 R)-9 \mathbf{b}, 60 \%$<smiles>C=C[C@H](C)[C@H]([OH2+])[C@@H](C)O[Mg]</smiles>

(3S,4R)-13a, 94\% $(3 R, 4 S)-13 \mathbf{b}, 86 \%$<smiles>CCC(=O)N1C(=O)OCC1Cc1ccccc1</smiles>

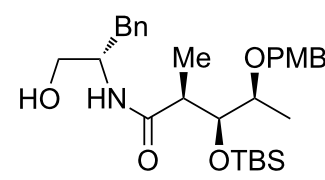

10a, $23 \%$

Scheme 1: Evans aldol reaction for the preparation of diastereomeric compounds $13 \mathbf{a}$ and $\mathbf{1 3 b}$.

After protection of the free hydroxy group, the reduction of the $\mathrm{N}$-acyl oxazolidinones $\mathbf{8}$ into primary alcohols $\mathbf{9}$ was accomplished by $\mathrm{LiBH}_{4}$ in presence of water or $\mathrm{LiAlH}_{4}$ [32]. What- ever the conditions used for this step, moderate yields were obtained for the desired products due to the formation of substantial amounts of ring-opened byproducts $\mathbf{1 0}$ resulting from the 
hydride addition to the carbonyl group of the oxazolidinone ring $[33,34]$. The alcohols 9 were then subjected to a Swern oxidation followed by a Wittig reaction to generate the corresponding alkenes 13a,b in $90 \%$ and $63 \%$ yield, respectively, over two steps. Alternatively, we envisioned that, from the same $\alpha$-substituted chiral aldehyde $\mathbf{5}$, compound $\mathbf{1 3 b}$ could be obtained in a more straightforward manner employing a strategy based on a diastereoselective allylboration reaction (Scheme 2) [35]. Indeed, the reaction of achiral pinacol $(Z)$-crotylboronate with $\mathbf{5}$ under neat conditions at room temperature gave a good level of diastereoselectivity for the hitherto unreported 3,4-syn-2,3-anti product 12b [36-39].

The syn relationship between $\mathrm{C} 3$ and $\mathrm{C} 4$ is controlled by the (Z)-geometry of the crotylboronate, while the 2,3-anti relationship can be rationalized by invoking Cornforth-like transition states [40-43]. Eventually, silylation of the homoallylic alcohol 12b afforded the expected compound $\mathbf{1 3 b}$ in $68 \%$ overall yield from 5 after purification, compared to $29 \%$ using a strategy based on an Evans' aldol reaction.

Mildly oxidizing conditions using 2,3-dichloro-5,6-dicyano-1,4benzoquinone (DDQ) were used for the removal of the p-methoxybenzyl (PMB) group to provide alcohols 14 (Scheme 3). Several palladium(II) catalysts have been tested for the conversion of alcohols to vinyl ethers 15 [13,44-46]. We found that the best yields were obtained using $\operatorname{Pd}(\mathrm{TFA})_{2}$ and $n$-butyl vinyl ether as solvent in the presence of bathophenanthroline as ligand. In the case of $\mathrm{Pd}(\mathrm{OAc})_{2}$, the reaction was slower with moderate yields.

The ring-closing metathesis reaction was performed with Hoveyda-Grubbs second-generation (HG-II) catalyst to deliver the corresponding dihydropyrans $\mathbf{1 6}$ in excellent yields given that this kind of reaction can be sensitive to the substitution pattern contained in the substrate [11]. After silyl deprotection, the key $\mathrm{C}-\mathrm{H}$ amination precursors $\mathbf{1 7} \mathbf{a}, \mathbf{b}$ for the synthesis of the carbamate-protected glycal of L-vancosamine 1 and L-saccharosamine 2 were prepared in two steps by treatment of alcohols with the trichloroacetyl isocyanate reagent (TCA-NCO) followed by basic hydrolysis. The spectroscopic properties of carbamates $\mathbf{1 7}$ were identical to those reported in the literature $[7,8]$. Although the intramolecular $\mathrm{C}-\mathrm{H}$ amination of compounds 17 under the Du Bois conditions [24] was already described in the literature $[8,9]$, the reaction was nevertheless achieved with carbamate $17 \mathbf{a}$ in order to check the reproducibility of the final step. As expected, L-vancosamine glycal 1 was obtained in similar yield than one reported $[8,47]$.

Synthesis of daunosamine and ristosamine glycals. As previously, the chiral pool material $\mathbf{5}$ was used for this unbranched glycal synthesis (Scheme 4). The first step was the chelationcontrolled addition of allylmagnesium bromide to 5 to provide the syn diastereomer 18 in high stereoselectivity (93:7). After

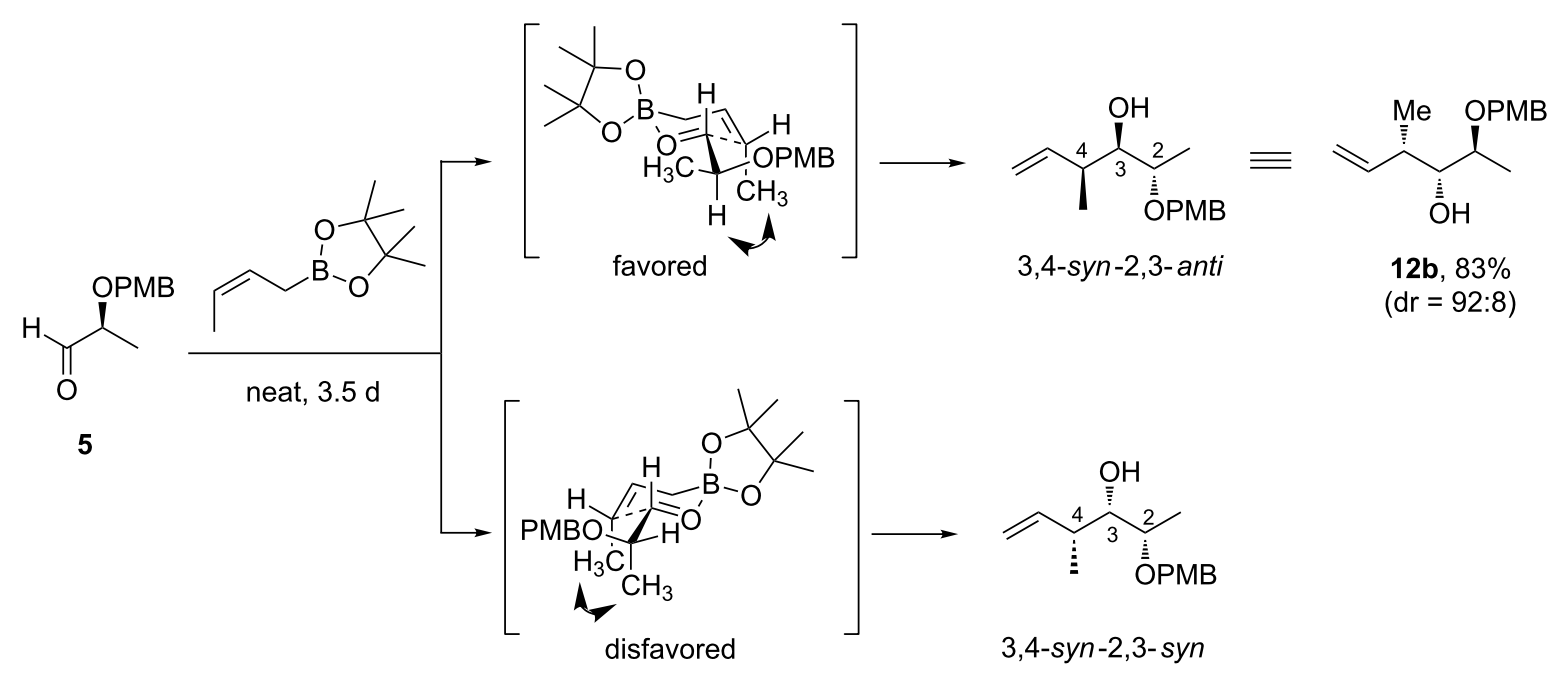

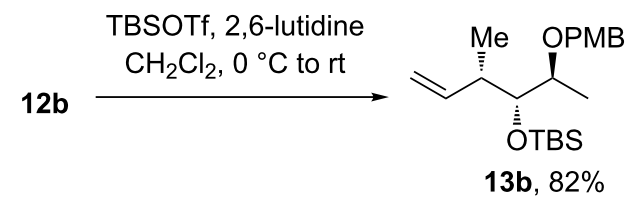




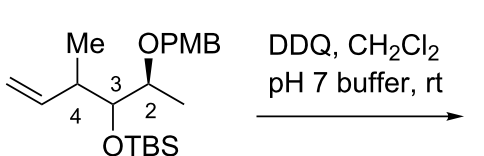

$(3 S, 4 R)-13 a$

$(3 R, 4 S)-13 \mathbf{b}$<smiles>C=CC(C)C(O[Sb](C)(=O)=O)C(C)O</smiles>

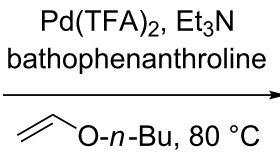

(3S, $4 R)-14 a, 84 \%$

(3R,4S)-14b, 93\%<smiles>C=COC(C)C(O[Sb])C(C)C=C</smiles>

HG-II (4 mol \%) toluene, $100{ }^{\circ} \mathrm{C}$<smiles>CC1C=CO[C@@H](C)C1O[SbH3]</smiles>

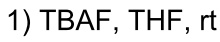

2) $\mathrm{Cl}_{3} \mathrm{CCONCO}$ $\mathrm{CH}_{2} \mathrm{Cl}_{2}$, rt

3) $\mathrm{K}_{2} \mathrm{CO}_{3}, \mathrm{MeOH}$, rt<smiles>CC1C=CO[C@H](C)C1OC(N)=O</smiles>

(3S, $4 R)-17 \mathbf{a}, 79 \%$ (3R,4S)-17b, $82 \%$

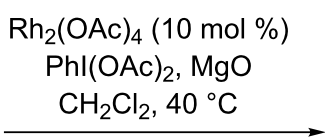

, 4 )-15a, $79 \%$

(3R,4S)-15b, 53\%

(3S, $4 R)-16 \mathbf{a}, 79 \%$

(3R,4 S)-16b, $82 \%$

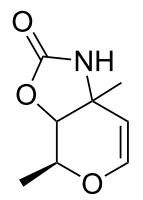

$1,80 \%$ from $17 a$

Scheme 3: O-Vinylation-ring-closing metathesis sequence for access to 3-amino glycals.

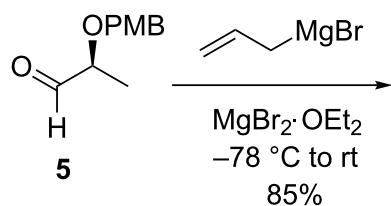<smiles>C=CC[C@@H](O)C(C)O[Mg]</smiles>

18

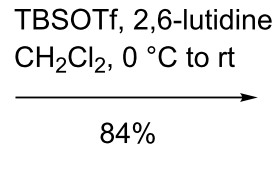<smiles>C=CCC([OH2+])[C@@H](C)OCC</smiles>

DDQ, $\mathrm{CH}_{2} \mathrm{Cl}_{2}$ $\mathrm{pH} 7$ buffer, rt

19
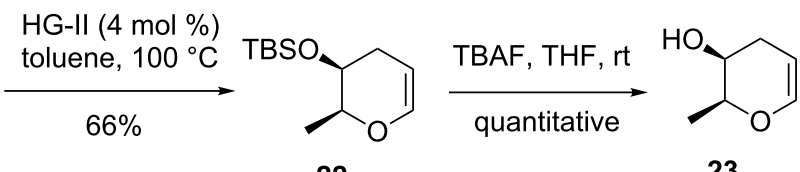

23

Scheme 4: Synthesis of key intermediate 23 for the C-3 unbranched amino glycals preparation.

silylation of the free hydroxy group, the cleavage of the PMB ether with DDQ led to alcohol 20 in $77 \%$ yield for the two steps. Ring-closing metathesis of diene 21, obtained by O-vinylation of $\mathbf{2 0}$, gave the dihydropyran $\mathbf{2 2}$ in $53 \%$ overall yield for two steps. The silyl group of compound $\mathbf{2 2}$ was cleaved using tetrabutylammonium fluoride (TBAF) in THF to form alcohol 23 which was used directly in the next step [48].

At this stage, we envisioned that $\mathbf{2 3}$ could be also a key intermediate to access the ristosamine derivative by reversing the configuration of the stereogenic center bearing the hydroxy group (Scheme 5). With this in mind, the secondary alcohol $\mathbf{2 3}$ was engaged in a Mitsunobu reaction using $p$-nitrobenzoic acid as nucleophile to afford the expected compound $\mathbf{2 5}$. Hydrolysis of the ester was achieved using potassium carbonate in methanol to afford the epimeric product $\mathbf{2 6}$.
Both diastereomers $\mathbf{2 3}$ and $\mathbf{2 6}$ were converted to the corresponding known carbamates using a two step sequence. Reaction with TCA-NCO followed by a basic hydrolysis provided the desired compounds $\mathbf{2 4}$ and $\mathbf{2 7}$ in good yields and in full agreement with all reported spectroscopic data [9]. As an example, the expected protected glycal of L-daunosamine 3 [9,47] was obtained by regioselective rhodium nitrene insertion thus demonstrating the usefulness of this strategy for the synthesis of such compounds.

\section{Conclusion}

We developed an alternative route to 3-aminoglycals through ring-closing metathesis of vinyl ethers as key step in the synthesis and using a common noncarbohydrate starting material. The approach was first validated for the synthesis of protected L-vancosamine glycal and extended afterwards to prepare a dia- 


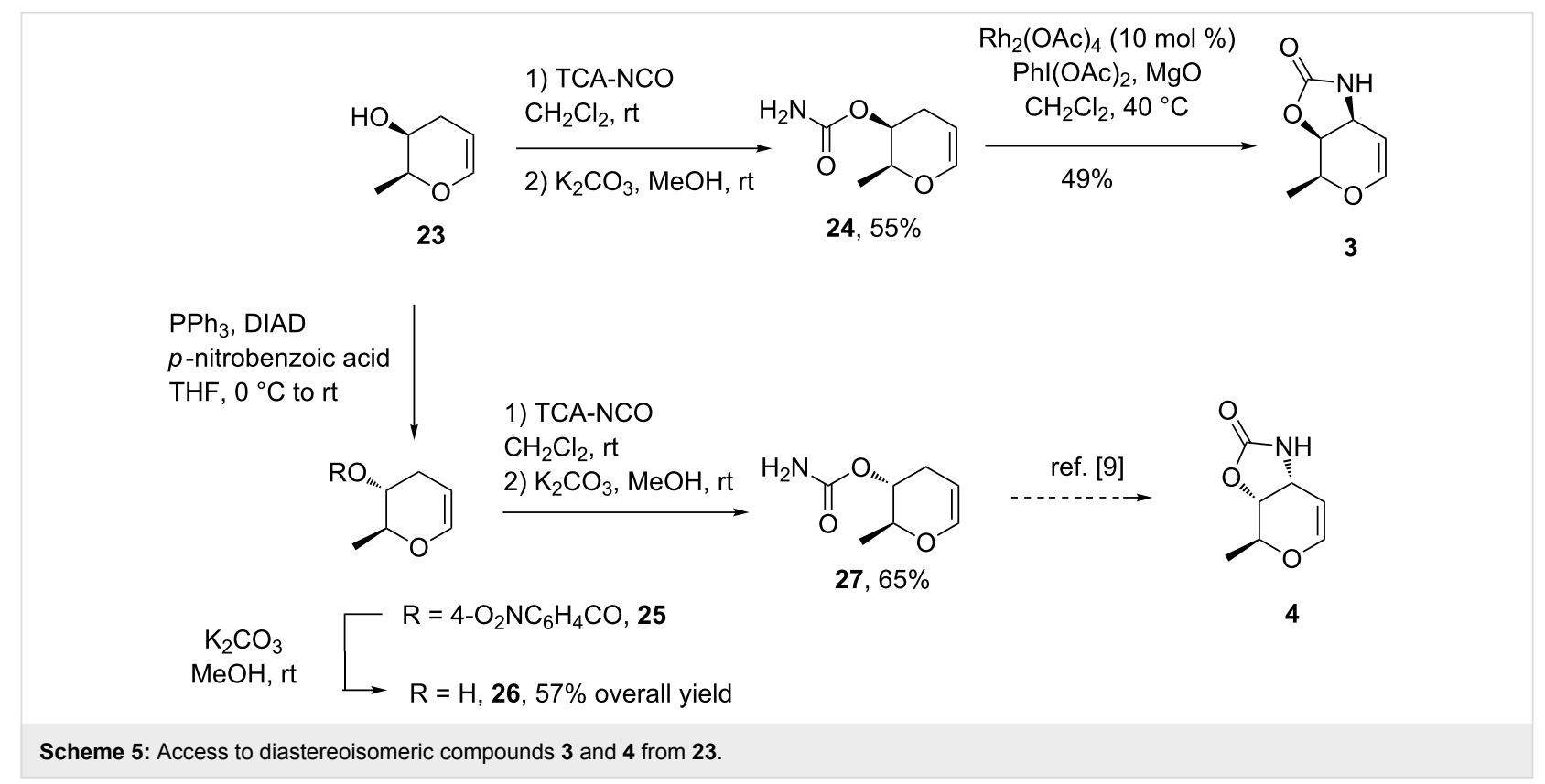

stereomeric compound as well as other unbranched C-3 aminoglycals. The use of these synthons in the synthesis of glycosylated antibiotics as kidamycin is underway in our laboratory.

\section{Supporting Information}

Supporting Information contains detailed experimental procedures with full characterization of all compounds and NMR spectra.

\section{Supporting Information File 1}

Experimental part and NMR spectra of all compounds. [https://www.beilstein-journals.org/bjoc/content/ supplementary/1860-5397-14-274-S1.pdf]

\section{Acknowledgements}

This work was supported by the University of Rennes 1 and the Centre National de la Recherche Scientifique (CNRS). One of us, P.-A. N. thanks ANR for a postdoctoral fellowship (ANR14-CE06-0008-01).

\section{ORCID ${ }^{\circledR}$ iDs}

Aurélie Macé - https://orcid.org/0000-0003-4783-1621 Sylvain Collet - https://orcid.org/0000-0002-7602-9585 Bertrand Carboni - https://orcid.org/0000-0003-0529-715X François Carreaux - https://orcid.org/0000-0002-7406-8353

\section{References}

1. Hauser, F. M.; Ellenberger, S. R. Chem. Rev. 1986, 86, 35-67. doi:10.1021/cr00071a003
2. Kitamura, K.; Ando, Y.; Matsumoto, T.; Suzuki, K. Chem. Rev. 2018, 118, 1495-1598. doi:10.1021/acs.chemrev.7b00380

3. Hartung, J.; Wright, B. J. D.; Danishefsky, S. J. Chem. - Eur. J. 2014, 20, 8731-8736. doi:10.1002/chem.201402254

4. Parker, K. A. Pure Appl. Chem. 1994, 66, 2135-2138. doi:10.1351/pac199466102135

5. Parker, K. A.; Koh, Y.-h. J. Am. Chem. Soc. 1994, 116, 11149-11150. doi:10.1021/ja00103a037

6. Danishefsky, S. J.; Bilodeau, M. T. Angew. Chem., Int. Ed. Engl. 1996, 35, 1380-1419. doi:10.1002/anie.199613801

7. Cutchins, W. W.; McDonald, F. E. Org. Lett. 2002, 4, 749-752. doi:10.1021/ol017195f

8. Parker, K. A.; Chang, W. Org. Lett. 2003, 5, 3891-3893. doi:10.1021/ol035479p

9. Parker, K. A.; Chang, W. Org. Lett. 2005, 7, 1785-1788. doi:10.1021/ol050356l

10. Fei, Z.; McDonald, F. E. Org. Lett. 2007, 9, 3547-3550. doi:10.1021/ol7014219

11. Sturino, C. F.; Wong, J. C. Y. Tetrahedron Lett. 1998, 39, 9623-9626. doi:10.1016/s0040-4039(98)02205-9

12. Gurjar, M. K.; Krishna, L. M.; Reddy, B. S.; Chorghade, M. S. Synthesis 2000, 557-560. doi:10.1055/s-2000-6376

13. Peczuh, M. W.; Snyder, N. L. Tetrahedron Lett. 2003, 44, 4057-4061. doi:10.1016/s0040-4039(03)00849-9

14. Postema, M. H. D.; Piper, J. L.; Liu, L.; Shen, J.; Faust, M.; Andreana, P. J. Org. Chem. 2003, 68, 4748-4754. doi:10.1021/jo030039x

15. Adam, J.-M.; de Fays, L.; Laguerre, M.; Ghosez, L. Tetrahedron 2004, 60, 7325-7344. doi:10.1016/j.tet.2004.05.058

16. Sharma, H.; Santra, S.; Debnath, J.; Antonio, T.; Reith, M.; Dutta, A. Bioorg. Med. Chem. 2014, 22, 311-324. doi:10.1016/j.bmc.2013.11.017

17. Sutton, A. E.; Seigal, B. A.; Finnegan, D. F.; Snapper, M. L. J. Am. Chem. Soc. 2002, 124, 13390-13391. doi:10.1021/ja028044q

18. Schmidt, B.; Biernat, A. Chem. - Eur. J. 2008, 14, 6135-6141. doi:10.1002/chem.200800567 
19. Majumder, U.; Cox, J. M.; Johnson, H. W. B.; Rainier, J. D. Chem. - Eur. J. 2006, 12, 1736-1746. doi:10.1002/chem.200500993

20. Osei Akoto, C.; Rainier, J. D. Angew. Chem., Int. Ed. 2008, 47, 8055-8058. doi:10.1002/anie.200803791

21. Clark, J. S.; Romiti, F.; Sieng, B.; Paterson, L. C.; Stewart, A.; Chaudhury, S.; Thomas, L. H. Org. Lett. 2015, 17, 4694-4697. doi:10.1021/acs.orglett.5b02093

22. Mabit, T.; Siard, A.; Pantin, M.; Zon, D.; Foulgoc, L.; Sissouma, D.; Guingant, A.; Mathé-Allainmat, M.; Lebreton, J.; Carreaux, F.; Dujardin, G.; Collet, S. J. Org. Chem. 2017, 82, 5710-5719. doi:10.1021/acs.joc.7b00544

23. Mabit, T.; Siard, A.; Legros, F.; Guillarme, S.; Martel, A.; Lebreton, J.; Carreaux, F.; Dujardin, G.; Collet, S. Chem. - Eur. J. 2018, 24, 14069-14074. doi:10.1002/chem.201803674

24. Espino, C. G.; Du Bois, J. Angew. Chem., Int. Ed. 2001, 40, 598-600. doi:10.1002/1521-3773(20010202)40:3<598::aid-anie598>3.0.co;2-9

25. Du Bois, J. Org. Process Res. Dev. 2011, 15, 758-762. doi:10.1021/op200046v

26. Evans, D. A.; Vogel, E.; Nelson, J. V. J. Am. Chem. Soc. 1979, 101, 6120-6123. doi:10.1021/ja00514a045

27. Evans, D. A.; Nelson, J. V.; Vogel, E.; Taber, T. R. J. Am. Chem. Soc. 1981, 103, 3099-3111. doi:10.1021/ja00401a031

28. Mukaiyama, T.; Inoue, T. Chem. Lett. 1976, 559-562. doi:10.1246/cl.1976.559

29. Cowden, C. J.; Paterson, I. Org. React. 1997, 1-200. doi:10.1002/0471264180.or051.01

30. Zhang, Z.; Collum, D. B. J. Org. Chem. 2017, 82, 7595-7601. doi:10.1021/acs.joc.7b01365 See for a mechanistic study of the Evans aldol reaction.

31. Roush, W. R.; Bennett, C. E.; Roberts, S. E. J. Org. Chem. 2001, 66, 6389-6393. doi:10.1021/jo015756a

32. Heravi, M. M.; Zadsirjan, V.; Farajpour, B. RSC Adv. 2016, 6, 30498-30551. doi:10.1039/c6ra00653a

33. Penning, T. D.; Djuric, S. W.; Haack, R. A.; Kalish, V. J.; Miyashiro, J. M.; Rowell, B. W.; Yu, S. S. Synth. Commun. 1990, 20 , 307-312. doi:10.1080/00397919008052299

34. Compound $10 \mathrm{~b}$ was not isolated.

35. Lachance, H.; Hall, D. G. Allylboration of carbonyl compounds. In Organic reactions; Denmark, S. E., Ed.; John Wiley \& sons: Hoboken, New Jersey, 2008; Vol. 73. doi:10.1002/0471264180.or073.01

36. Hoffmann, R. W.; Weidmann, U. Chem. Ber. 1985, 118, 3966-3979. doi:10.1002/cber.19851181010

37. Brinkmann, H.; Hoffmann, R. W. Chem. Ber. 1990, 123, 2395-2401. doi:10.1002/cber.19901231223

38. Wuts, P. G. M.; Bigelow, S. S. J. Org. Chem. 1988, 53, 5023-5034. doi:10.1021/jo00256a023

39. Roush, W. R.; Adam, M. A.; Walts, A. E.; Harris, D. J. J. Am. Chem. Soc. 1986, 108, 3422-3434. doi:10.1021/ja00272a043

40. Cornforth, J. W.; Cornforth, R. H.; Mathew, K. K. J. Chem. Soc. 1959, 112-127. doi:10.1039/jr9590000112

41. Roush, W. R. In Houben-Weyl, Stereoselective Synthesis; Helmchen, G.; Hoffmann, R. W.; Mulzer, J.; Schaumann, E., Eds.; Georg Thieme Verlag: Stuttgart, Germany, 1995; Vol. E21b, pp 1410-1486.

42. Cee, V. J.; Cramer, C. J.; Evans, D. A. J. Am. Chem. Soc. 2006, 128, 2920-2930. doi:10.1021/ja0555670

43. Díaz-Oltra, S.; Carda, M.; Murga, J.; Falomir, E.; Marco, J. A. Chem. - Eur. J. 2008, 14, 9240-9254. doi:10.1002/chem.200800956

44. Weintraub, P. M.; King, C.-H. R. J. Org. Chem. 1997, 62, 1560-1562. doi:10.1021/jo961182b
45. Handerson, S.; Schlaf, M. Org. Lett. 2002, 4, 407-409. doi:10.1021/ol017104e

46. Dechert-Schmitt, A.-M.; Cabral, S.; Kung, D. W. Synlett 2016, 27 , 2611-2615. doi:10.1055/s-0036-1588615

47. A very clean carbamate product is required to obtain a good conversion into oxazolidinone.

48. A partial loss of product can occur during evaporation under reduced pressure due to its low boiling point.

\section{License and Terms}

This is an Open Access article under the terms of the Creative Commons Attribution License

(http://creativecommons.org/licenses/by/4.0). Please note that the reuse, redistribution and reproduction in particular requires that the authors and source are credited.

The license is subject to the Beilstein Journal of Organic Chemistry terms and conditions:

(https://www.beilstein-journals.org/bjoc)

The definitive version of this article is the electronic one which can be found at:

doi:10.3762/bjoc. 14.274 